\title{
NOTES RELATING TO THE FLORA OF BHUTAN: XV
}

\author{
D. G. LONG
}

\begin{abstract}
Revision of Aquifoliaceae, Polygalaceae, Icacinaceae, Hippocrateaceae, Rhamnaceae, Malvaceae, Myrtaceae and Vitaceae has resulted in the following new taxa, new names and new combinations: Polygala sibirica L. subsp. bhutanica Kit Tan, subsp. nov., $P$. sibirica L. subsp. elegans (Wall. ex Royle) Kit Tan, comb. nov., P. sibirica L. subsp. heyneana (Wall. ex Wight \& Arnott) Kit Tan, comb. nov., Zizyphus rubiginosa Long \& Rae, sp. nov., Nayariophyton zizyphifolium (Griff.) Long \& Miller, comb. nov., Syzygium smalianum (Brandis) Long, comb. nov., and Tetrastigma corymbosum Long, sp. nov.. Notes on some critical Himalayan species of llex are provided, new lectotypes are designated for several names, and Salacia membranacea Lawson is shown to be a synonym of S. salacioides (Roxb.) Rao \& Hemadri.
\end{abstract}

\section{AQUIFOLIACEAE \\ by \\ SUSYN ANDREWS}

\section{NOTES ON EAST HIMILAYAN $I L E X$.}

Ilex dipyrena Wall. in Roxb., Fl. Ind. 1:473 (1820).

The first volume of 'Flora Indica' (Roxburgh, 1820) included plants described by William Roxburgh who had died in 1815. William Carey had taken over as editor, whilst the more recently discovered plants were written up by Nathaniel Wallich. The last plant to be described in that volume was Ilex dipyrena Wall. where Wallich implies that the description was based partly on his own Nepalese collections. As Wallich went to Nepal for the first time in November 1820 and did not return to India until 12 months later this can hardly be the case. Wallich Cat. 4327 (K-W, K), which was collected in 1821 (1831 on one sheet at Kew is an error), cannot therefore be type material. Thus any lectotype must be selected from the other collections cited in the protologue, namely Govan s.n. (n.v.) and Webb s.n. (BM).

Ilex godajam (Colebr.) Hook.f., F1. Brit. India 1:604 (1875).

Basionym: Prinos godajam Colebr. in Wall., Pl. Asiat. Rar. 3:38, t.261 (1832).

Prinos godajam was published in Wallich (loc. cit.) with Colebrooke as the validating author. Two elements were cited in the protologue: a. Silhet, Gomez and b. Jolpigory, Hamilton. Both these specimens are syntypes; the Hamilton collection has been seen at $\mathrm{K}$ and $\mathrm{E}$, but the Gomez specimen has not been located. The combination under Ilex was first validly made by Hooker (loc. cit.).

Ilex sikkimensis Kurz, J. Asiat. Soc. Bengal 44(2): 202 (1875).

Kurz (loc. cit.) based his description of this species on a yellow-fruited variant from the wild. Comber (1933) later described red-fruited plants collected by George Forrest 
in Yunnan as var. coccinea Comber thus making all the yellow-berried specimens var. sikkimensis. Unless plants are collected in fruit and the fruit colour noted, the two taxa cannot be distinguished.

\section{Polygalaceae \\ by \\ KIT TAN}

In revising Himalayan material of Polygala, the plant referred to by Bennett (1872) and Hara \& Williams (1979) as P. elegans Wall. ex Royle, has proved not to be specifically distinct from the widespread $P$. sibirica. In the Himalaya it comprises two discrete taxa which are treated as subspecies: subsp. bhutanica, which is described as new, from Sikkim, Bhutan, Assam and Burma, and subsp. elegans, from Nepal and NW Himalaya. In south India a third member of the aggregate occurs ( $P$. heyneana) which is likewise treated as a subspecies of $P$. sibirica.

Polygala sibirica L. subsp. bhutanica Kit Tan, subsp. nov.

A subsp. sibirica foliis latioribus puberulentibus, alisque fere symmetricis haud falcatis differt; a subsp. eleganti (Wall. ex Royle) Kit Tan alis capsulisque non ciliatis recedit et a subsp. heyneana (Wall, ex Wight \& Arnott) Kit Tan capsulis non ciliatis, foliis nec subcoriaceous non supra valde reticulatovenosis distinguitur.

Perennis herbacea suffrutescens $10-30 \mathrm{~cm}$ alta. Caules tenues, exalati, e basi ramosi, crispato-pubescentes. Folia anguste elliptica usque elliptico-lanceolata, (5-)15-40 $\times$ $2-7 \mathrm{~mm}$, apiculata, viridia, puberulentia ad subglabra, supra non valde reticulatovenosa, infra secus venas et marginem paulo involutam puberulentia vel sparse puberulentia; petiola minus quam $0.5 \mathrm{~mm}$ longa. Racemi $2-10 \mathrm{~cm}$ longi, fructiferi elongati. Bracteae bracteolaeque caducae. Flores intense caeruleo-violacei ad purpureo-malvini. Sepala exteriora ovato-navicularia, c. $3.5 \mathrm{~mm}$, subacuta, ciliata, viridia marginibus membranaceis albis roseisve; ala paene symmetrica, non falcata, ellipticospathulata, 5-7mm longa, ad margines glabra, persistentia. Carina $5-7 \mathrm{~mm}$ longa, crista laciniata. Filamenta in partem superiorem tertiam vel dimidiam libera. Stylus curvatus. Capsula anguste alata, suborbicularis, 5-6 6 c.6.5mm, emarginata, ad margines glabra. Semina ovoidea, c. $2.5 \times 2 \mathrm{~mm}$, e rubro-nigra, albopilosa; arillus parvus, inaequaliter trilobus.

Type: Bhutan, Thimphu district, Drugye Dzong, Paro Chu, c.2650m, in hard dry soil in open situations, 11 v 1949, Ludlow \& Sherriff 16197 (holo. E, iso. BM).

BHUTAN: without locality, 1838, Griffith 1767 (K). Ha district: Ha, 2770m, vi 1933, Ludlow \& Sherriff 115 (BM, E). Thimphu district: Dorbjir Dzong, 1830m, iv 1915, Cooper 3821 (E); Pumola area, 3660m, v 1938, Gould 203 (K); Dukye Dzong, NW of Paro, 2800m, vi 1975, Grierson \& Long 229 (E); above Motithang Hotel, c.2450m, vi 1975, Grierson \& Long 85 (E); Taba, c.2375m, v 1979, Grierson \& Long 932 (E). Tongsa district: $7 \mathrm{~km}$ S of Shamgong, c. $1850 \mathrm{~m}$, iv 1982, Grierson \& Long 4204 (E). Bumthang district: Byakar, c.2750m, vi 1979, Grierson \& Long 1811 (E).

SIK KIM: Lachung, 2440m, Hooker s.n. (K); Chungthang, 1830m, iv 1938, Lister 76 (K). ASSAM: Manipur, Susi Kamain, 910m, iv 1882, Watt 6244 (E, K); Manipur, Noung 
Shong Khong valley, 1220m, iv 1882, Watt 6291 (E, K); Naga Hills, Losani, 1370m, iii 1935, Bor 2948 (K); Lohit Valley, 610m, iii 1928, Ward 7953 (K); Subansiri Division, SW corner of Apa Tani valley, 1650m, iv 1965, Cox \& Hutchison 340 (E, K).

BURMA: Shan Hills plateau, 1220m, iii 1888, Collett 492 (K).

Open pastures, grassy banks, in scrub, at margins of Pine forest, by streams, roadsides etc., $610-3660 \mathrm{~m}$. Flowering March July.

The following new combinations are necessary:

Polygala sibirica L. subsp. elegans (Wall. ex Royle) Kit Tan, comb. nov.

Syn.: P. elegans Wall.ex Royle, Ill. Bot. Himal. Mts. 76 (June 1834);

P. elegans Wall., Numer. List 147 (1831), nom. nud.; P. sibirica

L. var. elegans (Wall. ex Royle) Hara, J. Jap. Bot. 47:272

(1972). Type: Nepal, Wallich in Wall. Cat No. 4186 (K-W).

P. myrsinites Royle, op. cit. t.19, f.A. (March 1834).

Polygala sibirica L. subsp. heyneana (Wall. ex Wight \& Arnott) Kit Tan, comb. nov.

Syn.: P. heyneana Wall. ex Wight \& Arnott, Prodr. Fl. Ind. Orient., 1:38 (1834); P. heyneana Wall., Numer. List 147 (1831), nom. nud.; P. sibirica L. var. heyneana (Wall. ex Wight \& Arnott) Bennett, in Hook. f., F1. Brit. India 1:205 (1872). Syntypes: India, Heyne in Wall. Cat. $4184(\mathrm{~K}-\mathrm{W})$; Nilgiri, Wight Cat. $128(\mathrm{E}), 129(\mathrm{E}), 132(\mathrm{E})$.

$P$. venosa Heyne in Wall., loc. cit. (1831), nom. nud.

Subsp. elegans, occurring in the NW Himalaya and Nepal, can be distinguished from subsp. bhutanica by the ciliate wing sepals and capsules. Subsp. sibirica is widespread, occurring from C Europe to N Korea, southwards to Kashmir, Nepal and Assam. Nepalese material often has narrower, greyish-green, acute to apiculate, pubescent leaves and symmetrical, falcate wing sepals. The south Indian subsp. heyneana with ciliate capsules and more oblong, obtuse \pm coriaceous leaves strongly reticulateveined above, is absent from Bhutan and Sikkim.

\section{ICACINACEAE}

Miquelia assamica (Griff.) Long, comb. nov.

Basionym: Jenkinsia assamica Griff., Calcutta J. Nat. Hist. 4:231 (1843); ibid. t.12 (1844); Notulae Pl. Asiat. 4:370 (1854); Ic.Pl.Asiat. t.537 f.2 (1854). Type: India, Assam, prope Suddyah, 3 ii 1836, Griffith K.D.825, hb. E.I.C. 140 (holo. K, iso. E).

Syn.: Miquelia kleinii auct. p.p. non Meisner.

From the revision of Olacaceae in the Flora of British India by Masters (1875) up to the recent revision of Asiatic Icacinaceae by Sleumer (1969), Jenkinsia assamica Griff. has been treated as a synonym of Miquelia kleinii Meisner, in many publications. Following the interesting discovery of the genus Miquelia in Bhutan in 1982, type materials of the two taxa were located. Study of these and other specimens indicates that two distinct isolated species are involved, $M$. assamica in Bhutan and Assam, 
and M. kleinii s.str. in south India. The combination $M$. assamica appears not to have been validly published hitherto.

Miquelia kleinii is a rare species apparently known only from the type collections of male plants. It is characterized by its broadly oblong-ovate leaves truncate or subcordate at the base, with margins somewhat dentate in the lower half, its very long slender male peduncles $60-70 \mathrm{~mm}$, and its almost glabrous young shoots and inflorescences.

$M$. assamica differs in its narrower, elliptic leaves cuneate or narrowly rounded at the base, with entire or shallowly sinuate margins, the shorter male peduncles, 10$40 \mathrm{~mm}$, and finely strigose-pubescent young shoots and inflorescences.

The following specimens of $M$. assamica have been seen in addition to the type:

ASSAM: without locality (male), Griffith s.n. (K); Khasia, Nongpriang, 305m, (female), xi 1871, Clarke 15023 (BM,K); Makum, Luckimpore, 90m, (male), iv 1885, Clarke 37817 (K); ibid., (female), Clarke 37825 (BM); Sonari, Seebsangur, (male), iv 1885, Clarke 38010 (K,E); Dibroogarh, 90m, (male), iv 1885, Clarke 367769 (E); Dumur Dullung, Sibsagar, (male), iv 1895, Watt 10436 (K); Bhramaputra Plains, (female), Kurz s.n. (BM).

BHUTAN: Gaylegphug district, Karai Khola above Aie Bridge, Gaylegphug, 26 55' N, 90³3'E, 510m, (male), iii 1982, Grierson \& Long 3947 (E).

Miquelia kleinii Meisner, Pl. Vasc. Gen. 2:109 (1838); Aralia kleinii (Meisner) Steudel, Nomencl. Bot. ed.2,1:118 (1841). Type: Peninsula Ind. Orient., ex herb. Klein in herb. Wight propr. 1211 (holo. E-GL, iso. K).

Syn.: Araliacea? kleinii Wight \& Arnott, Prodr. Fl. Ind. Orient. 375 (1834), nom. inval. (Art. 34.1).

The first description of this plant was published by Wight \& Arnott (1834) under the name 'Araliacea? kleinii Wight Cat. 1211' together with the comment 'Our specimens were obtained from Klein's herbarium; there was no name or locality attached'. Thus the type locality remains doubtful but it is likely to have come from southern peninsular India (Burkill, 1965).

\section{Hippocrateaceae}

Salacia salacioides (Roxb.) Rao \& Hemadri, J. Bombay Nat.Hist. Soc. 67:358 (1970); Johnia salacioides Roxb. ex Roxb., Fl. Ind. 1:172 (1820); Roxb., Hort. Bengal. 5(1814) nom.nud. Type: 'Native of Tipperah, Chittagong and other parts of the eastern frontier of Bengal'; Roxb. Icones no. 1520 (K).

Syn.: Salacia roxburghii Wall. ex Wight \& Arnott, Prod. Fl. Ind. Orient. 105 (1834), nom. superfl.; Wall., Cat. 4217 (1831) nom. nud.

S. membranacea M. Lawson in Hook. f., F1. Brit. India 1:627 (1875), syn. nov. Type: India, Khasia, 600-900m, Hooker \& Thomson 2330 (lecto. selected here K).

Limited herbarium collections of this species has hindered its full understanding in the past. Rao \& Hemadri (1970) correctly reinstated the epithet 'salacioides' for the plant, to which the further synonym S. membranacea can now be added. 
The following additional specimens have been seen; those collected by Haines labelled 'British Bhotan' are not from Bhutan (where the genus remains unrecorded) but from the Kalimpong area of West Bengal, India.

DARJEELING DISTRICT: 'Sikkim', Hooker s.n. (K); Mongpo, 910m, vi 1874, Gamble 2726A (K); Tingleng, 1220m, x 1875, Clarke 25432 (BM); Khumani forest, 305m, xii 1904, Haines 1040 (E,K); Lower Fagu, British Bhotan, 460m, ii 1905, Haines 1048 (E,K); Rongbe, $910 \mathrm{~m}$, vi 1913, Cave s.n. (E).

ASSAM: Amwee, Khasia, $600-900 \mathrm{~m}$, ix 1850, Hooker \& Thomson s.n. (syntype of $S$. membranacea $\mathrm{M}$. Lawson, $\mathrm{K}$ ).

BANGLADESH: Sylhet, De Silva in Wallich Cat. $4217 \mathrm{~b}(\mathrm{E})$.

CULT.INDIA: Hort. Bot. Calcutta, Wallich Cat. $4217 \mathrm{c}$ (E,K).

\section{RHAMNACEAE}

\section{Zizyphus rubiginosa Long \& Rae, sp. nov. Fig.1.}

Z. rugosa Roxb. similis sed caulibus aculeisque porphyreo-pubescentibus differt; folia membranacea, anguste ovata, ad acuminas truncatas contracta; basi rotundata obliqua neque cordata; margines paucioribus maioribusque serraturis; venae subtus pilosae, aliter glabra; paniculae maiores usque ad $36 \mathrm{~cm}$ altas, dense castaneo-tomentosae.

Extensive climbing shrub, stems red-brown pubescent and with pale lenticels, bearing short stout recurved reddish-pubescent prickles up to $4 \mathrm{~mm}$ at nodes. Leaves alternate, membranous, narrowly ovate, $9-15 \times 4-7 \mathrm{~cm}$, acuminate to a narrow truncately tipped acumen, base rounded, oblique, margin serrulate, strongly 3-veined from base to apex, veins prominent beneath, reticulations transverse, weak, sparsely hairy on veins beneath otherwise glabrous; petiole $8-11 \mathrm{~mm}$; stipules not seen. Panicles large, leafless, $26-30 \mathrm{~cm}$, softly red-brown tomentose throughout; branches cymose, pedicels $2-4 \mathrm{~mm}$. Flowers cream. Calyx lobes 5 , ovate, $2.5-3 \mathrm{~mm}$, tomentose outside glabrous and with median rib within. Petals absent. Stamens 5. Disc shallowly 5lobed, glabrous. Ovary partly immersed in disc, free part hairy; style divided to middle, lower part hairy, lobes sparsely hairy. Fruit unknown.

Type: Bhutan: Sarbhang district, above Noonpani, $16 \mathrm{~km}$ along Sarbhang to Chirang road, $26^{\circ} 55^{\prime} \mathrm{N}, 90^{\circ} 15^{\prime} \mathrm{E}$, warm broad-leaved forest slopes, $890 \mathrm{~m}$, 'Prickly climbing shrub, flowers creamy', 8 iii 1982, Grierson \& Long 3582 (holo. E, iso. K).

DARJEELING DISTRICT: Jalpaiguri duars, iii 1893, Haines 337 (K), 337a (K).

ASSAM: Dening Reserve (Digboi/ Hugrijan Road), 75m, ii 1973, Tessier-Yandell 266

(K).

BURMA: Myitkyina District, Nuzabya Reserve, Mansi Division, iii 1929, Su Koe 9223

(K); Upper Chindwin District, Nan-kaung-kyen, 300m, iii 1927, Chin 5808 (K).

Zizyphus rubiginosa is a distinctive new species known from the Darjeeling Terai, $\mathrm{S}$ Bhutan, Assam and Burma. Its apetalous flowers borne in large leafless panicles, and prickly climbing habit indicate a close affinity with only one other Indian species, $Z$. rugosa Roxb., which is a widespread species throughout India, Ceylon, Bangladesh, Burma and in the foothills of Nepal and Sikkim. It is not yet recorded from Bhutan. However, Z. rugosa appears to differ consistently in its broadly ovate or elliptic leaves 


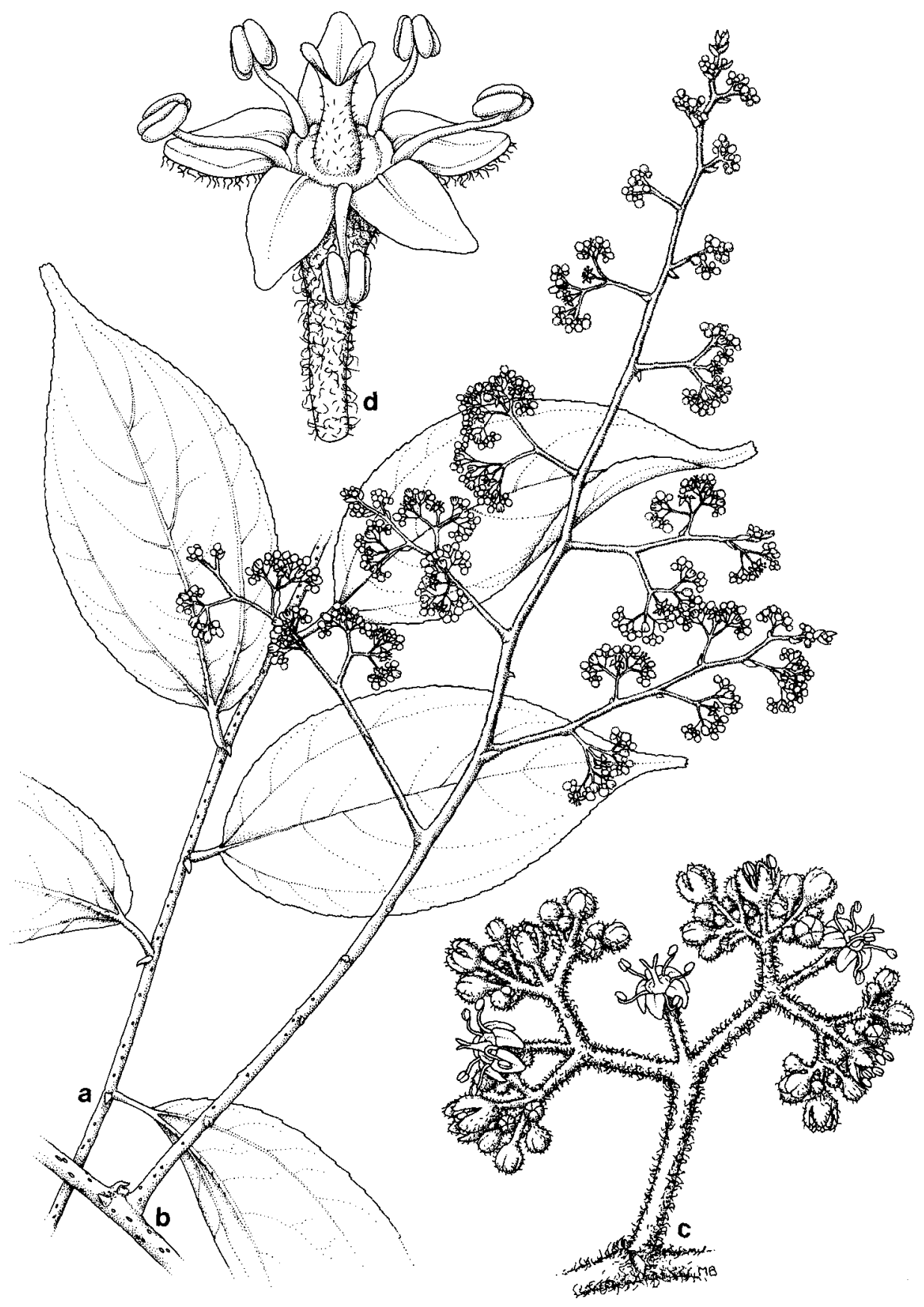

FIG. 1. Zizyphus rubiginosa. a, part of leafy shoot $\times \frac{1}{2}$; $\mathrm{b}$, flowering panicle $\times \frac{1}{2}$; $\mathrm{c}$, part of flowering panicle $\times 2$; d, flower x7. Drawn from holotype by Mary Bates. 
which are thick in texture with an obtuse or shortly and bluntly pointed apex, often shallowly cordate base, more finely serrulate margin and softly tomentose lower surface, as well as in the pale brown or fawn-tomentose panicles.

\section{Malvaceae}

Nayariophyton zizyphifolium (Griff.) D.G. Long \& A.G. Miller, comb. nov. Syn.: Kydia zizyphifolia Griff., Itin. Notes 108 (1848). Type: Bhutan, Dewangiri [= Deothang], 914m, Griffith Itin. No. 120, Herb. E.I.C. 1752 (lecto. selected here $\mathrm{K}$, iso. K). Kydia jujubifolia Griff., Notulae 4:534 (1854), Icon. Pl. Asiat. t.595 (1854), nom. illeg. (incl. typ. spec. prior); Dicellostyles jujubifolia (Griff.) Benth. in Benth. \& Hook. f., Gen. Pl. 1:207 (1862); Nayariophyton jujubifolium (Griff.) T.K. Paul, Bot. Jahrb. Syst. 110: 43 (1988).

Bentham (1862) described the genus Dicellostyles to include two species: D. jujubifolia from the East Himalaya and D. axillaris from Sri Lanka. No lectotype for Dicellostyles has been formally designated, although Paul (1988) restricted the genus to D. axillaris and segregated the disjunct Himalayan member as a new genus, Nayariophyton. However, in describing this new genus he overlooked the existence of an earlier valid epithet for the same species, Kydia zizyphifolia Griff. which antedates the epithet jujubifolia by six years and renders the latter illegitimate. Hence the new combination must be made. It is surprising that the earlier epithet was overlooked, because the protologue of Kydia jujubifolia lacks any description but clearly refers back to the earlier description of $K$. zizyphifolia; the two names are therefore based on the same description and type.

\section{MYRTACEAE}

Syzygium smalianum (Brandis) Long, comb. nov.

Syn.: Eugenia smaliana Brandis, Indian Trees 320 (1906). Type: Burma, Hmangin, Schwebo District, 760m, vi 1921, Smale s.n. (? holo. K).

BURMA: Amherst District, spur to Muleyit from Mikalaung Chg., 1065m, i 1912, Lace 5615 (E, K); Hukong Valley, vi 1921, Hole 48 (K).

BHUTAN: Sarbhang District, between Noonpani and Tori Bari, 16km along Chirang Road, $26^{\circ} 55^{\prime} \mathrm{N}, 90^{\circ} 15^{\prime} \mathrm{E}, 990 \mathrm{~m}$, iii 1982, Grierson \& Long 3651 (E).

ASSAM: North Cachar Hills, 1065-1220m, i 1972, Tessier-Yandell 139 (K).

The above specimens apparently constitute new records for both India and Bhutan. In line with modern thinking (Smid, 1972) this species should be considered as a member of the genus Syzygium and the necessary combination is therefore made. 


\section{VITACEAE}

Tetrastigma rumicispermum (M. Lawson) Planchon in A. \& C. DC., Mon. Phan. 5: 429 (1887).

Basionym: Vitis rumicisperma M. Lawson, Fl. Brit. India 1: 661 (1875). Type: Sikkim, Tungblee , 1500-2100m, 'an immense climber' Hooker 168 (lecto. selected here K).

Lawson (1875) in describing Vitis rumicisperma included in the protologue a range of collections from Nepal, Sikkim and Khasia collected by Wallich, Hooker and others. No type was indicated. In Hooker's herbarium at Kew there are at least eight sheets which qualify as syntypes, annotated by Lawson as Vitis rumicisperma. Most of these belong to the plant traditionally called Tetrastigma rumicispermum, but two sheets (one a mixed collection) represent a second taxon not distinguished by name. This second element is a new species described below. A lectotype is therefore desirable to stabilize the application of the name Tetrastigma rumicispermum in the traditional sense. Because Lawson emphasized the fruit characters of the species, a fruiting specimen has been selected as lectotype.

\section{Tetrastigma corymbosum Long, sp. nov. Fig. 2.}

T. rumicispermae (M. Lawson) Planchon et T. aplinianae (Coll. \& Hemsley) Momiyama similis sed plantis omnino glabris differt; foliola elliptico-oblanceolata, mar-

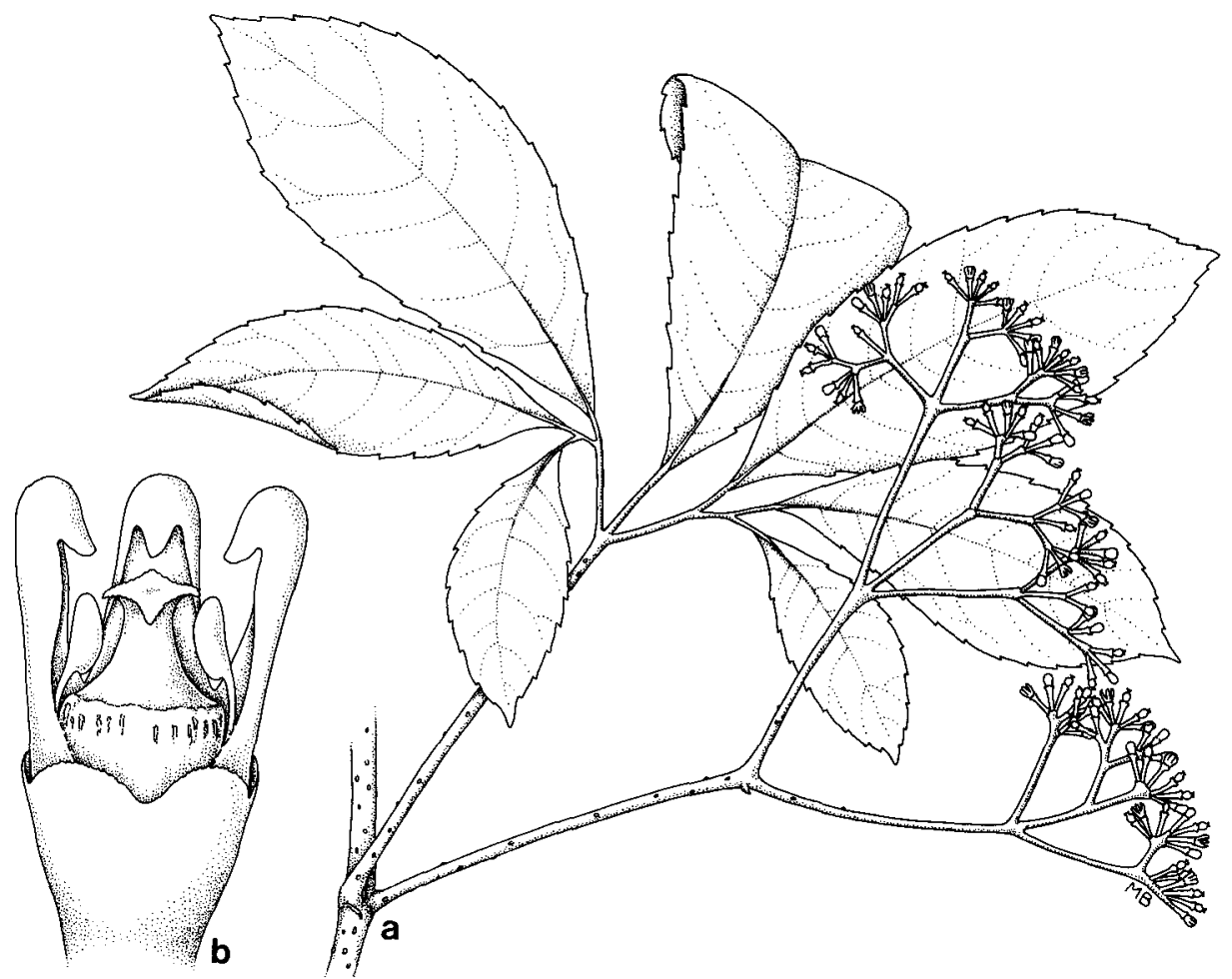

FIG. 2. Tetrastigma corymbosum. a, leaf and female inflorescence $\times \frac{1}{2}$; $b$, female flower with one petal and one stamen removed $\times 14$. Drawn from holotype by Mary Bates. 
ginibus aculeo-serratis; cymae amplae, $8-12 \mathrm{~cm}$ diametro, corymbosae, in pedunculis carnosis $5-9 \mathrm{~cm}$ longis; styli breves crassique.

Large climbing shrub, glabrous throughout, main branches with scattered pale lenticels, older stems strongly warted; tendrils leaf-opposed, stout, bifid, never borne on peduncles. Leaves pedately 5-7-foliate; petioles $6-11 \mathrm{~cm}$; stipules caducous, not seen. Leaflets thinly coriaceous, elliptic-oblanceolate, $6.5-17 \times 2-6 \mathrm{~cm}$, acuminate, base cuneate, often oblique, margin sharply serrate. Flowers functionally unisexual, in pseudo-axillary corymbose cymes 6-12cm diam.; peduncle somewhat fleshy, 3$9 \mathrm{~cm}$; pedicels fleshy, thickened towards apex. Calyx minute, cup-shaped, shortly lobed. Petals 4 , white, ovate, c. $2 \mathrm{~mm}$, tapering above to a thickened blunt point, free and spreading at anthesis, caducous. Stamens reduced to staminodes in functionally female flowers. Male flowers not seen. Disc cup-shaped, adnate to base of ovary; apex of ovary tapering into short thick style, bearing 4 short spreading lobes. Fruit obovoidsubglobose, 2-3-seeded.

Type: Bhutan, Mongar district, near Zimgang, Shongar Chu near Mongar, $27^{\circ} 17^{\prime} \mathrm{N}$, $91^{\circ} 05^{\prime} \mathrm{E}, 1475 \mathrm{~m}$, warm broad-leaved forest, 'Large climbing shrub', 15 vi 1979, Grierson \& Long 1970 (holo. E; iso. K, TI, THIMPHU)

DARJEELING DISTRICT: without precise locality, 1525m, vi 1923, Cowan s.n. (E); Choonbuttee, 910m, vi 1875, Clarke 26576b (BM); Dumsong, 1830m, i 1912, Ribu \& Rhomoo s.n. (E).

ASSAM: Khasia Hills, Churra, 1220-1830m, vi 1850, Hooker \& Thomson 707 (K); Shillong, 1280m, vii 1886, Clarke 4413lb (BM).

Tetrastigma corymbosum belongs to a group within the genus which contains four other East Himalayan species characterized by their pedately 5-7-foliate leaves: $T$. aplinianum (Coll. \& Hemsley) Momiyama, T. dubium (M. Lawson) Planchon, $T$. leucostaphylum (Dennst.) Mabberley (T. lanceolarium (Roxb.) Planchon), $T$. rumicispermum (M. Lawson) Planchon, and T. serrulatum (Roxb.) Planchon. T. corymbosum is characterized principally by its thinly coriaceous leaflets with strongly serrate margins, glabrous corymbose cymes $6-12 \mathrm{~cm}$ diameter and very short thick style.

T. dubium differs in its lanceolate leaflets, small compact cymes and petals ending in a subulate point. $T$. serrulatum differs in its much smaller leaflets with marginal teeth reduced to subulate excurrent vein-tips, and smaller cymes. T. leucostaphylum differs in its larger more coriaceous leaflets and dense puberulous cymes. T. rumicispermum is closely related but differs in its membranous, distinctly obovate leaflets with minute projecting vein-tips (as in T. serrulatum), shorter densely puberulous cymes and a more distinct and slender style. T. aplinianum differs in its thickly coriaceous leaflets with coarsely but distantly serrate margins and large, paniculate puberulous inflorescences.

\section{ACKNOWLEDGEMENTS}

The Keepers of the herbaria at Kew and the British Museum (Natural History) are thanked for loan of specimens, A.J.C. Grierson for help with some of the Latin diagnoses, and Mary Bates for art work. 


\section{REFERENCES}

Bennett, A. W. (1872). Polygaleae. In Hooker, J. D. (ed.) Flora of British India, 1:200-211. London.

Bentham, G.(1862). Malvaceae. In Bentham, G. \& Hooker, J. D., Genera Plantarum 1:195-213. London.

BuRkill, I. H. (1965). Chapters on the history of Botany in India. Botanical Survey of India, Calcutta.

COMBER, H. F. (1933). Notes on the distribution of certain Chinese and Himalayan species of Ilex with descriptions of new species. Notes from the Royal Botanic Garden Edinburgh 18:37-62.

Hara, H. \& Williams, L. H. J. (1979). An Enumeration of the Flowering Plants of Nepal. Vol.2. London.

Lawson, M. A. (1875). Ampelidae. In HoOKer, J. D. (ed.) Flora of British India, 1:644-668. London.

Masters, M. T. (1875). Olacineae. In Hooker, J. D. (ed.) Flora of British India, 1:572-598. London.

PaUL, T. K. (1988). Nayariophyton: a new genus of Malvaceae from North Eastern Himalaya. Botanische Jahrbücher für Systematik, Pflanzengeschichte und Pflanzengeographie 110:41-46.

RAO, R. S. \& HeMadRI, K. (1970). Nomenclatural notes on Indian plants. Journal of the Bombay Natural History Society 67:357-358.

RoXBURGH, W. (1820). Flora Indica. Vol.1. Serampore.

Sleumer, H. (1969). Materials towards the knowledge of the Icacinaceae of Asia, Malesia, and adjacent areas. Blumea 17:181-264.

SMID, R. (1972). A resolution of the Eugenia-Syzygium controversy (Myrtaceae). American Journal of Botany 59:423 436.

Wight, R. \& Arnott, G. A. W. (1834). Prodromus Florae Peninsulae Indiae Orientalis. London. 